\title{
Neomodernisme Islam dalam Perspektif Fazlur Rahman
}

\author{
Hanna Widayani \\ Institut Agama Islam Negeri Bengkulu \\ e-mail: hanawidayani2810@gmail.com
}

\begin{abstract}
According to observers of Islamic thought, Fazlur Rahman is a figure whose thoughts are categorized as neomodernism, a pattern of thought that combines modern and traditional thought. Modernism, according to this pattern, is not something to be rejected, but modernism does not mean that the nature of traditionalism must be set aside. This is certainly in line with the Islamic thought of Fazlur Rahman who is always in developing his thoughts to see the development of past thoughts. In some cases, even the two realms of thought (modernism and traditionalism) can go hand in hand. If people follow Fazlur Rahman's way of thinking in all his works according to Syafi'i Ma'arif, people will know that he is very interested in developing the awareness of Muslims about their historical responsibilities with a solid moral foundation. This foundation can only be created if the Koran as a source of perfect moral teaching is understood in full and unified. This true and complete understanding must be done through a methodology that can be accounted for in a religious and scientific manner. According to Rahman, without an accurate and correct methodology, an understanding of the content of the Qur'an may be misleading, especially when approached partially and separately.
\end{abstract}

Keyword: Neomodernism, Islam, Fazlur Rahman

\begin{abstract}
Abstrak
Menurut para pemerhati pemikiran Islam, Fazlur Rahman adalah tokoh yang pemikirannya dikategorikan sebagai neomodernisme yaitu suatu pola pemikiran yang menggabungkan antara pemikiran modern dan tradisional. Modernisme menurut pola ini, bukanlah sesuatu yang harus ditolak, melainkan dengan modernisme bukan pula berarti alam pemikrian tradisionalisme harus dikesampingkan. Hal ini tentunya sejalan dengan pemikiran Islam Fazlur Rahman yang senantiasa dalam mengembangkan pemikirannya melihat perkembangan pemikiran masa lalu. Dalam beberapa hal, bahkan kedua alam pemikiran (modernisme dan tradisionalisme) bisa berjalan seiring. Apabila orang mengkuti jalan pemikiran Fazlur Rahman dalam seluruh karyanya menurut Syafi'i Ma'arif, orang akan tahu bahwa ia sangat berkepentingan mengembangkan kembali kesadaran umat Islam akan tanggung jawab sejarahnya dengan pondasi moral yang kokoh. Pondasi ini hanya mungkin diciptakan apabila al-Qur'an sebagai sumber ajaran moral yang sempurna dipahami secara utuh dan padu. Pemahaman yang benar dan utuh ini harus dikerjakan melalui suatu metodologi yang dapat dipertanggungjawabakan secara agama dan secara ilmu. Menurut Rahman, tanpa suatu metodologi yang akurat dan benar, pemahaman terhadap kandungan al-Qur'an boleh jadi menyesatkan, apalagi bila didekati secara parsial dan terpisah.
\end{abstract}

Kata Kunci: Neomodernisme, Islam, Fazlur Rahman

Pendahuluan

Paham modern (modernisme) adalah pandangan yang didasarkan pada keyakinan bahwa dengan adanya kemajuan ilmu pengetahuan dan perkembangan budaya-budaya kontemporer, mengharuskan penganutnya untuk menafsirkan kembali ajaran-ajaran agama 
yang dianggap ortodoks, dengan menggunakan standar pemahaman filsafat dan metode ilmiah yang aktual. Makna modernisme seperti itu seperti itu didasarkan pada asumsi dasar bahwa perkembangan pemikiran atau paham keagamaan ortodoks yang dipengaruhi oleh kondisi zaman yang aktual pada masanya tidak sejalan lagi dengan kondisi kemajuan dan perkembangan ilmu pengetahuan saat ini. Apabila pemikiran atau paham keagamaan tersebut akan diterapkan pada zaman sekarang, haruslah diadakan penyesuaian terlebih dahulu dengan kondisi saat ini. ${ }^{1}$

Memasuki era modern, perubahan sosial yang berlangsung secara dramatis sebagai infiltrasi kebudayaan Barat yang dibarengi kolonialisasi Barat yang dibarengi kolonialisasi Barat atas hampir seluruh dunia Islam, telah memunculkan sejumlah pembaharuan yang berkenaan dengan relevansi agama bagi dunia modern. Tantangan yang dihadapi kaum Muslimin pada periode modern ini dirasakan sangat berat dan memiliki implikasi serius terhadap masa depan agama. Tantangan itu berupa seranganserangan para kritikus Barat terhadap Islam dan benturan-benturan kebudayaan

\footnotetext{
1 Syahrin Harahap, Islam dan Modernitas (Dari Teori Modernisasi Hingga Penegakan Kesalehan Modern), (Jakarta: Prenadamedia Group, 2015), h. 83-84
}

Barat, yang memasuki dunia Islam lewat kolonialisasi.

Setelah kaum Muslimin memperoleh kemerdekaan dari kekuasaan Kolonial, modernisme di neger-negeri Muslim pada umumnya berkiblat ke Barat. Modernisasi semacam ini telah melempangkan jalan bagi terciptanya masyarakat industri yang berdampak bagi perubangan sistem berpikir dan struktur sosial. Struktur feodal warisan abad pertengahan terlihat musnah di bawah pengaruh industrialisasi, yang pada gilirannya masyarakat industri ini akan mengalami transformasi dan bergeser menjadi masyarakat informasi yang pasti akan membawa tantangan lebih berat lagi. $^{2}$

Perkembangan modern dalam Islam menemukan momentumnya pada abad ke 19, meskipun dasar-dasarnya sudah muncul sejak beberapa abad sebelumnya. Momentum yang dimaksud adalah adanya gerakan politik dan intelektual yang mulai menjamah ke berbagai kawasan negeri-negeri Islam. Tema-tema gerakan itu umumnya berkisar pada dua hal, protes melawan kemerosotan internal dan serangan eksternal. Kebangkitan itu tidak berarti bahwa sebelumnya Islam dalam kondisi

2 Abu Hasan Ali Nadawi dkk, Benturan Barat Dengan Islam, (Bandung : Mizan, 1993), h. 14 
sedemikian pasif untuk menghadapi perubahan demi perubahan yang terjadi. Pada kenyataannya suatu peradaban tidak lain adalah hasil akumulasi perjalanan pergumulan pemeluk agama yang berdimensi historis dengan ajaran wahyu yang bernilai normatif. Proses dialektis antara keduanya berjalan dari waktu ke waktu dengan diwarnai oleh tingkat dinamika yang bervariasi, ada kalanya berjalan cepat dan menghasilkan perubahan besar, tetapi terkadang juga berjalan lambat dan membawa perubahan yang tidak begitu berarti. Diantara faktor terpenting yang menentukan arus perubahan itu adalah sejauh mana gerakan pembaruan dapat terimplementasi secara nyata dalam kehidupan. ${ }^{3}$

Secara sederhana gerakan pembaruan dalam Islam atau sering diistilahkan dengan tajdid, dapat diartikan sebagai upaya baik secara individual maupun kelompok pada kurun waktu tertentu untuk mengadakan perubahan dari persepsi dan praktek keislaman yang telah mapan kepada bentuk pemahaman dan pengamalan baru. Gerakan pembaruan ini umumnya berpangkal pada asumsi bahwa Islam sebagai realitas

${ }^{3}$ Ahmad Amir Aziz, Pembaruan Teologi Perspektif Modernisme Muhammad Abduh dan Neomodernisme Fazlur Rahman, (Yogyakarta: Teras, 2009), h. 1-2 sosial pada lingkungan tertentu tersebut sudah tidak lagi relevan atau bahkan menyimpang dari apa yang dipandang sebagai Islam yang sesungguhnya. Tentu saja bagaimana tafsiran Islam ideal tersebut sangat dipengaruhi oleh cara pandang, pendekatan, latar belakang sosio-kultural dan keagamaan masingmasing pembaharu. Karena corak epistimologi gerakan yang beragam inilah maka melahirkan model pembaruan yang bermacam-macam yang sering ditipologikan misalnya dengan reformisme, modernisme, puritanisme, fundamentalisme, sekularisme dan neomodernisme. ${ }^{4}$

Dalam pada itu gerakan pemikiran modern abad ke-20 meskipun banyak mengambil inspirasinya dari periode sebelumnya, tetaplah memiliki karakteristiknya sendiri. Seorang pemikir yang mengindektikkan dirinya sebagai neo-modernis adalah Fazlur Rahman. ${ }^{5}$ Tidak seperti pembaru yang sebelumsebelumnya, Rahman memperoleh pendidikan formal sejak dini, bahkan sampai menyelesaikan jenjang pendidikan tertinggi. Pembaru kelahiran Pakistan ini mulanya dibesarkan melalui pendidikan Islam tradisional namun pada

\footnotetext{
${ }^{4}$ Ahmad Amir Aziz, Pembaruan Teologi..., h. 2

${ }^{5}$ Fazlur Rahman, Metode Alternatif Neomodernisme Islam, (Bandung: Mizan, 1993), h. 18
} 
perkembangan selanjutnya ia mengenyam pendidikan di Barat sampai kemudian mengambil program Doktornya di Universitas Oxford Inggris. Dengan latar belakang ini menjadikan Rahman sosok intelektual muslim yang kritis dan cukup berani dalam melontarkan gagasangagasan pembaruannya.

Begitu ia kembali ke negerinya, Pakistan sudah merupakan tempat yang ramai dan bahkan menjadi ajang kontroversi pemikiran Islam yang menarik antara kubu modernis dan tradisionalis, dengan begitu posisi Rahman berada pada pihak pertama. Karena kalangan modernis yang berkuasa di pemerintahan maka Rahman lah yang ditunjuk memimpin sebuah Lembaga Riset Islam yang bertugas menggodok ideide Islam dan bagaimana mengaktualkannya dalam Negara Islam yang belum lama berdiri itu. Masing-masing Islamic Studies yang berbahasa Inggris dan Fikr-u Nazhr yang berbahasa Urdu. Melalui jurnal-jurnal inilah Rahman mengaktualkan ide-idenya. ${ }^{6}$

Rahman mempetakan pola-pola gerakan pembaruan di dunia Islam, yang kemudian mengilhaminya untuk menawarkan model baru. Menurutnya,

6 Taufik Adnan Amal dan Ihsan Ali Fauzi, Fazlur Rahman: Sang Sarjana Sang Pemikir, (Jakarta: Lembaga Studi Agama dan Filsafat, 1988), h. 26 gerakan modernisme klasik meskipun telah benar dalam semangatnya namun memiliki dua kelemahan mendasar: pertama, ia tidak menguraikan secara tuntas metodenya yang berguna untuk menangani kasus-kasus tertentu yang sering muncul. Mungkin karena perannya selaku reformis terhadap masyarakat muslim dan sekaligus sebagai kontroversialis-apologetik terhadap Barat menyebabkan kelompok ini terhalang untuk melakukan interpretasi sistematis dan menyeluruh atas doktrin Islam. Kedua, masalah-masalah ad hoc yang ditangani kaum modernis sering berasal dari Barat, sehingga terdapat kesan kuat bahwa mereka tidak mampu menciptakan diskursus sendiri, lebih jauh mereka merupakan agen-agen westernisasi belaka.

Berpijak dari sinilah Rahman menggagas gerakan barunya yang ia sebut sebagai neo-modernisme. Karakteristik utama gerakan ini menurutnya adalah pengembangan suatu metodologi sistematis yang mampu melakukan rekonstruksi Islam secara total dan tuntas serta setia kepada akar-akar spiritualnya dan dapat menjawab kebutuhankebutuhan Islam modern, tanpa mengalah secara membabi buta kepada Barat atau menafikannya. Disamping itu neomodernisme juga hendak bersikap kritis 


\section{Hanna Widayani \\ NEDMDDERNISME ISLAM DALAM PERSPEKTIF FAZLLIR RAHMAN}

terhadap warisan-warisan sejarah keagamaannya. ${ }^{7}$

Beberapa gagasan Rahman yang mewarnai neomodernisme Islam nya itu tidak jarang mendapat kecaman yang pedas dari banyak ulama dan cendekiawan. Hal tersebut lebih disebabkan karena banyak ide-idenya yang melawan arus pemikiran yang telah mapan, terlebih para ulama tradisional. Sekalipun banyak mendapat tantangan, namun secara diam-diam pemikiran Rahman tersebut mulai banyak dilirik oleh beberapa kalangan. Hal tersebut diawali setelah kepulangan terlebih setelah karya-karya Rahman dan kedua muridnya itu diterjemahkan ke dalam bahasa Indonesia. Pengaruh neomodernisme Islam Rahman terhadap kedua muridnya begitu kentara dengan terbukti pada setiap tulisannya. ${ }^{8}$

\section{Biografi Fazlur Rahman}

Fazlur Rahman dilahirkan pada tahun 1919 M di distrik Hazara, Punjab, ${ }^{9}$ suatu daerah di anak benua Indo-Pakistan yang sekarang terletak di sebelah Barat

\footnotetext{
7 Ahmad Amir Aziz, Pembaruan Teologi..., h. 6

8 Muhammad Azhar, Fiqih Kontemporer Dalam Pandangan Neomodernisme Islam, (Yogyakarta: Pustaka Pelajar, 1996), h. 52

9 Taufik Adnan Amal, Metode dan Alternatif NeoModernisme Islam Fazlur Rahman, (Bandung: Mizan, 1993), h. 13
}

Laut Pakistan. ${ }^{10}$ Ia dibesarkan dalam suatu keluarga dengan tradisi keagamaan mazhab Hanafi yang cukup kuat. Oleh karenanya, sebagaimana diakuinya sendiri bahwa ia telah terbiasa menjalankan ritual-ritual agama, seperti shalat dan puasa secara teratur sejak masa kecilnya dan tidak pernah meninggalkannya. ${ }^{11}$ Dasar pemahaman keagamaan keluarganya yang cukup kuat itu dapat ditelusuri dari ayahnya yang bernama Maulana Shihab ad-Din. Seorang ulama tradisional kenamaan lulusan Dar al‘Ulum, Deoband. Maulana Shihab ad-Din sendiri adalah seorang ulama modern, meskipun terdidik dalam pola pemikiran Islam tradisional.

Ayahnya tersebut memiliki keyakinan bahwa Islam melihat modernitas sebagai tantangan-tantangan dan kesempatan-kesempatan yang harus dihadapi. Keyakinan seperti ini pulalah yang kemudian dimiliki dan mewarnai kehidupan dan pemikiran Fazlur Rahman. ${ }^{12}$ Ketika ia berusia 14 tahun, bersama orang tuanya dari tempat leluhur asalnya ke Lahore yang saat itu disebut sebagai 'Kota Taman dan Perguruan

10 Syukri Saleh, Metodologi Tafsir Kontemporer Dalam Pandangan Fazlur Rahman, (Jambi: Sulthan Thaha Press, 2007), h. 2

${ }^{11}$ Fazlur Rahman, Islam, terj. Senoaji Saleh, (Jakarta: PT Bumi Aksara, 1987), h. 35 
Tinggi'. Di sinilah Rahman memasuki pendidikan formalnya di sekolah modern. Tetapi dalam pada itu, ayahnya mengajarkan mata pelajaran-pelajaran tradisional dalam kajian keislaman di rumahnya. ${ }^{13}$

Bekal dasar tersebut memiliki pengaruh signifikansi yang cukup berarti dalam pembentukan kepribadian dan intelektualitas Rahman pada masa-masa selanjutnya. Melalui didikan ayahya, Rahman menjadi sosok yang cukup tekun untuk menimba pengetahuan dari berbagai sumber dan media, termasuk karya-karya Barat. Pengajaran dan pendidikan tradisional ilmu-ilmu keislaman pada waktu kecil beliau terima dari ayahnya di rumah. Pada usia 10 tahun, Rahman pun dapat menghafal AlQur'an. Selanjutnya pada usia 14 tahun, ia sudah mulai belajar filsafat, bahasa Arab, teologi, hadis dan tafsir. Apalagi setelah beliau menguasai beberapa bahasa asing, seperti bahasa Persia, Urdu, Inggris, Perancis, Jerman, Latin dan Yunani, semakin memperteguh kualitas intelektualitasnya. ${ }^{14}$

12 Abd. A'la, Dari Neomodernisme ke Islam Liberal: Jejak Fazlur Rahman Dalam Wacana Islam Indonesia, (Jakarta: Yayasan Wakaf Paramadina, 2003), h. 33

13 Harun Nasution, Pembaharuan Dalam Islam, Sejarah Pemikiran dan Gerakan, (Jakarta: Bulan Bintang, 1975), h. 162

14 Nurcholis Madjid, Fazlur Rahman dan Rekonstruksi Etika Al-Qur'an, (Jakarta: Islamika, 1993), h. 23
Pengaruh ayah dan ibunya tersebut sangat kuat dalam membentuk kerangka pemikiran dan pengamalan keagamaan Rahman. Sang ayah yang di didik dalam pola pemikiran Islam tradisional. Namun toleran terhadap nilainilai modernitas sebagai kenyataan seharihari. Dari ibunya diajarkan nilai-nilai kebenaran, kasih sayang, ketabahan dan cinta. Kedua orang tuanya ikut memberikan bekal yang cukup signifikan dan mendasar terhadap pembentukan kepribadian dan keintelektualan Rahman pada masa selanjutnya. Hal lain yang mempengaruhi Rahman adalah tradisi mazhab Hanafi yang dianut oleh keluarganya dan ini yang membentuk pola pemikirannya dalam hal keagamaan. Tradisi mazhab Hanafi dikenal sebagai salah satu mazhab Sunni yang mengedepankan akal-logika. Ini menjadi modal landasan berpikir Rahman untuk selalu berada di lajur pemikiran keagamaan yang bercorak rasional. Meskipun demikian, beliau tidak mau dikungkung oleh satu mazhab tertentu. ${ }^{15}$

Pemikiran keagamaan Rahman juga banyak dipengaruhi pola pemikiran kalangan modernis dan sedikit tokohtokoh liberal Pakistan sebelumnya sebagaimana yang diajarkan oleh Syah

${ }^{15}$ Fazlur Rahman, Islam..., h. 36 
Waliyullah ad-Dihlawi, Sayyid Ahmad Khan, Sayyid Amir Ali,16 dan Muhammad Iqbal,17 pada masa ini umat Islam di India sedang bergejolak dan berjuang membentuk negara sendiri yang bebas dari India, yaitu suatu Negara yang berlandaskan ajaran Islam. Pada tahun 1940, Rahman menyelesaikan studinya pada program Bachelor of Art. Dan dua tahun kemudian ia meraih gelar Master dalam bahsa Arab. Kedua gelar ini diperolehnya dari Universitas Punjab, Lahore. Namun gelar yang diperoleh dari perguruan tinggi di anak benua itu tampaknya lebih bersifat fomalitasakademia dibandingkan dengan aspeknya yang bersifat intelektual. Hal ini terbukti dari pernyataannya sendiri bahwa Pakistan tidak dapat menciptakan suatu dasar intelektual. ${ }^{18}$ Tentunya yang dimaksud dengan pernyataannya itu ialah dalam pengertian dasar intelektual yang memadai. Kritiknya terhadap sistem pendidikan Islam tercermin dari ungkapannya berikut: "Bila bahan bakar minyak bumi lenyap dari dunia, mungkin ada gantinya. Tetapi bila Islam yang

16 Harun nasution, Pembaharuan Dalam Islam: Sejarah Pemikiran dan Gerakan, (Jakarta: Bulan Bintang, 1992), h. 181

${ }^{17}$ Muhammad Iqbal adalah salah seorang penyair, filsuf, ahli hukum, pemikir politik, dan reformis Muslim. Djohan Effendi, Pengantar ke Pemikiran Iqbal, (Bandung: Mizan, 1985), h. 13

${ }^{18}$ Fazlur Rahman, Islam dan Modernity, (Chicago, The University of Chicago Press, 1982),h. 117 lenyap, gantinya tidak akan ada lagi."19 Hal ini menunjukkan komitmen dan keprihatinan Rahman terhadap kondisi pendidikan dan intelektual umat Islam pada masa itu.

\section{Pembaharuan Neo-Modernisme Islam} Fazlur Rahman

Memasuki era modern, perubahan sosial yang berlangsung secara dramatis sebagai infiltrasi kebudayaan Barat yang dibarengi kolonialisasi Barat atas hampir seluruh dunia Islam, telah memunculkan sejumlah pembaharuan yang berkenaan dengan relevansi agama bagi dunia modern. Tantangan yang dihadapi kaum Muslimin pada periode modern ini dirasakan sangat berat dan memiliki implikasi serius terhadap masa depan agama. Tantangan itu berupa seranganserangan para kritikus Barat terhadap Islam dan bentura-benturan kebudayaan Barat, yang memasuki dunia Islam lewat kolonialisasi.

$$
\text { Setelah kaum Muslimin }
$$
memperoleh kemerdekaan dari kekuasaan kolonial, modernisme di negeri-negeri Muslim pada umumnya berkiblat ke Barat. Modernisasi semacam ini telah melapangkan jalan bagi terciptanya masyarakat industri yang berdampak bagi 
perubahan sistem berpikir dan struktur sosial. Struktur feodal warisan abad pertengahan terlihat musnah di bawah pengaruh industrialisasi, yang pada gilirannya masyarakat industri ini akan mengalami transformasi dan bergeser menjadi masyarakat informasi yang pasti akan membawa tantangan yang lebih berat lagi. Lebih lanjut, modernisasi negeri-negeri Muslim juga telah memperlancar arus penyebaran berbagai paham ke dunia Islam, seperti sosialisme, ateisme, atau sekulerisme yang kesemuanya itu membutuhkan perenungan keagamaan yang serius. Karena itu, pembaharuan keagamaan dan hadirnya sejumlah pembaharuan dalam menjawab permasalahan tersebut sangat diperlukan, dan apabila mengalami kegagalan dalam upaya pembaharuan pemikiran tersebut, maka akan menimbulkan sejumlah masalah besar yang serius. ${ }^{20}$

$$
\text { Sebagai seorang intelektual }
$$

Rahman yang memperoleh pendidikan formal sampai jenjang tertinggi tentu mempunyai sejarah sendiri dalam kaitannya dengan perkembangan pemikiran. Disebutkan bahwa Rahman pada dasarnya mempunyai dasar-dasar

\footnotetext{
${ }^{19}$ Ahmaad Syafii Maarif, Peta Bumi Intelektual Islam, (Bandung: Mizan, 1994), h. 135

${ }^{20}$ Abu Hasan Ali Nadawi dkk, Benturan Barat..., h. 15

disiplin tradisional keislaman, namun karena perkembangan studi lanjutnya di Barat maka arus pemikirannya tidak dapat dilepaskan dari tradisi intelektual yang berkembang disana. Dengan pengalaman didikan dua jalur tersebut menjadikan Rahman mempunyai karakter yang khas. Karakter pemikiran yang kemudian disebut sebagai cikal bakal Neo-Modernisme Islam dapat ditelusuri melalui perkembangan pemikirannya lewat tulisan dan karya-karya yang dihasilkan dari waktu ke waktu. ${ }^{21}$

Diantaranya karya yang terbit menjelang tahun 1960-an adalah Propechy in Islam: Philosophy and Ortodoxy (1956). Buku ini dapat disebut hasil terpenting pemikiran Rahman pada masa awal perkembangan pemikirannya mengingat isinya yang cukup serius dalam membahas salah satu dimensi penting dalam doktrin Islam. Penulisan buku ini dilatarbelakangi oleh kenyataan kurangnya perhatian dari pada sarjana modern yang mengkaji pemikiran keagamaan khususnya tentang doktrin kenabian. Sesuai dengan tema buku, tahapan pemikiran Rahman berada dalam tengah-tengah antara garis ortodoksi dan filosofi, hanya ia bersikap kritis atas pandangan-pandangan kedua kelompok

${ }^{21}$ Ahmad Amir Aziz, Pembaruan Teologi..., h. 68 
ini. Pernyataan Rahman sendiri jelas sekali menunjukkan hal tersebut;

Dalam buku itu saya mendiskusikan bentrokan pokok antara pandanganpandangan para teolog Islam tradisional dan pandangan-pandangan para filosof muslim yang menurunkan teori mereka mengenai hakikat agama dari ajaran-ajaran filsafat Yunani. Secara intelektual para filosof memang benar-benar pintar, memukau dengan argumen-argumen mereka yang ruwet, tetapi Tuhan mereka tetap merupakan suatu prinsip yang kekurangan darah-melulu merupakan konstruksi intelektual tanpa kekuatan maupun imajinasi. Sementara itu meskipun kurang terampil secara intelektual, para teolog Islam tradisional secara instinktif menyadari menyadari bahwa Tuhan suatu agama adalah Tuhan yang berdarah sangat segar (fullblooded), realitas hidup yang memberi respon kepada doa-doa, menuntun manusia baik secara individual maupun kolektif, dan terlibat dalam sejarah. ${ }^{22}$

Kemudian khususnya dalam bidang hukum, Rahman pernah menulis serangkaian artikel yang dimuat dalam jurnal Islamic Studies sejak 1962-1963. Artikel-artikel tersebut dan setelah ditambah dengan yang lain pada dua tahun kemudian diedit ulang dan diterbitkan menjadi sebuah buku dengan judul Islamic Methodology in History (1965). Secara umum buku ini berisi kajian kritis Rahman terhadap keempat sumbersumber pemikiran hukum Islam dan

22 Fazlur Rahman, An Autobiographical Note, (New York: Ballatine Bookers, 1985), h. 153 bagaimana aplikasinya dalam sejarah. Karena gagasan-gagasan baru yang dimunculkan Rahman dalam buku ini cukup banyak maka ia pun mengakui sulitnya bagi kalangan tradisionalis untuk mengikuti alur pemikirannya.

Pemikiran Rahman pada periode Pakistan, sebelum kepindahannya ke USA lebih didominasi oleh wacana kemoderenan dalam memberikan ulasan, penilaian dan pendiriannya atas berbagai masalah. Dalam aspek teoritis kajian Rahman banyak diarahkan pada persoalan-persoalan religio-filosofis yang hendak mencari jalan keluar dari kemelut ketegangan antara jenis pemahaman filosofis dan non filosofis. Sedangkan dalam aspek praksis Rahman secara intens terlibat dalam usaha pencarian identitas keislaman bagi negeri Pakistan. Kedua sisi aspek teoritis dan praksis ini tidak berhasil dikembangkan secara maksimal oleh Rahman karena suasana Pakistan yang kurang kondusif.

Kemudian pada periode Chicago, terlihat perkembangan intelektual yang berarti dalam diri Rahman. Satu karya penting yang dihasilkan adalah berjudul Islam and Modernity : Transformation of an intellectual Tradition (1982). Buku ini memperlihatkan secara jelas betapa intensnya Rahman dalam member 
alternatif dan menata masa depan Islam dan umatnya. Sebagian besar buku ini berkisar kajian kritis Rahman mengenai sejarah intelektual dan pendidikan Islam sejak periode klasik hingga dewasa ini. Pada bagian akhir karya tersebut ia mencatat perlunya rekonstruksi intelektualisme Islam dan untuk itu ia menawarkan beberapa konsep dasar. Pertama, umat Islam harus mampu membedakan antara Islam normatif dan Islam historis. Kedua, perlunya rekonstruksi ilmu-ilmu Islam yang meliputi teologi, hukum, etika, filsafat dan ilmu-ilmu sosial. ${ }^{23}$

Periode Chicago dapat disebut sebagai babak baru pemikiran Rahman yang mana ide menonjolnya terlihat pada wawasannya ke depan. Dalam masa ini pula ia menghasilkan pemikiran tentang periodesasi dan tipologi gerakan Islam dari waktu ke waktu yang menurutnya dapat dikelompokkan ke dalam empat model: 1.) Revivalisme Pra modernisme, 2.) Modernisme Klasik, 3.) NeoRevivalisme dan 4.) Neo-Modernisme.

Gerakan Revivalisme pra modernis muncul abad ke 18 dan 19 seperti Wahabi di Arabia, Sanusi di Afrika dan gerakan pemurnian lain di India, yang menurut Rahman mempunyai ciri-ciri umum

${ }^{23}$ Ahmad Amir Aziz, Pembaruan Teologi..., h. 78- sebagai berikut; a) menampakkan keprihatinan yang mendalam terhadap degenerasi sosio-moral umat Islam dan usaha untuk mengubahnya. b) imbauan untuk kembali kepada Islam yang orisinil dan mengenyahkan takhayul-takhayul yang tertanam dalam bentuk sufisme popular. c) imbauan untuk meninggalkan faham predeterministik. d) seruan untuk melaksanakan pembaruan lewat kekuatan bersenjata (jihad) jika perlu.

Dasar pembaruan revivalisme pra modernis kemudian diambil oleh gerakan kedua yaitu Modernisme klasik yang muncul pada pertengahan abad ke 19 dan awal ke 20 di bawah pengaruh ide-ide Barat. Persamaannya dengan pembaruan sebelumnya terletak pada seruannya tentang ijtihad dan penolakannya atas taqlid. Yang baru pada kaum modernis klasik adalah perluasan mereka tentang isi dan cakupan ijtihad. Lingkungan mereka telah berubah dari apa yang dihadapi oleh kaum revivalis, dan mereka lebih terbuka kepada gagasan-gagasan Barat yang sedang menghangat dan yang mempunyai kemungkinan berkembang di masa depan semisal hubungan akal dan iman, pembaruan sosial dalam pendidikan, status wanita dalam keluarga dan masyarakat, serta pembaruan politik 
dalam bentuk pemerintahan yang representatif dan konstitusional. ${ }^{24}$

Selanjutnya, dari pembaruan yang dimunculkan oleh modernisme klasik di atas telah memberikan inspirasi bagi munculnya gerakan pembaruan ketiga yaitu Neo-revivalisme. Gerakan ketiga ini mendasarkan dirinya pada basis pemikiran gerakan sebelumnya yaitu bahwa Islam mencakup segala aspek kehidupan manusia baik individual maupun kolektif. Ciri yang paling menonjol dari tipologi gerakan adalah sikapnya yang anti-Barat secara total. Perlu dicatat bahwa karena sebagian neorevivalisme merupakan penerimaan dan sebagian lagi merupakan reaksi terhadap modernisme klasik, maka pada dasarnya neo-revivalisme muncul dan tumbuh di belahan-belahan dunia islam yang mana modernisme klasik muncul lebih dahulu.

Dengan berpijak pada kajiannya atas karakteristik ketiga gerakan pembaruan di atas, Rahman mencanangkan suatu gerakan baru yang disebutnya dengan Neo-modernisme. ${ }^{25}$ Ciri utama dari gerakan baru ini adalah pengembangan suatu metodologi sistematis yang mampu melakukan rekonstruksi Islam secara total dan tuntas

\footnotetext{
${ }^{24}$ Ahmad Amir Aziz, Pembaruan Teologi..., h. 81

25 Fazlur Rahman, Islam Challenges and Opportunities, (Eidenburgh: University Press, 1979), h. 317
}

serta setia kepada akar-akar spiritualnya dan dapat menjawab kebutuhankebutuhan Islam modern tanpa mengalah secar membabi buta kepada Barat atau menafikannya sama sekali. Demikian pula terhadap warisan-warisan kesejarahan Islam, neo-modernisme akan bersikap kritis. Sikap kritis terhadap Barat yang diajukan Rahman kiranya dapat dipahami oleh banyak kalangan dengan pengertian bahwa yang baik harus diambil-alih sedangkan yang buruk harus ditolak. Jadi ini merupakan pandangan yang tidak terlalu unik. Yang tajak dalam pemikiran Rahman adalah usulnya atas kajian kritis terhadap warisan keislaman.

Dalam pandangannya tradisi bukanlah kumpulan warisan masa lampau yang statis dan tidak berubah, melainkan proses yang dinamis dan terus berubah yang harus diarahkan sejalan dengan prinsip-prinsip yang diturunkan dari Qur'an dan Sunnah. Dengan demikian dalam konteks ini penting bag Rahman untuk membedakan antara yang 'Islami' dan 'yang murni historis'. Inilah yang mengantarkannya kepada pembedaan antara Islam normatif dan Islam historis. Kriteria Islamitas menurutnya adalah bahwa suatu doktrin atau institusi itu benar-benar Islami jika ia 
memancar dari totalitas ajaran Qur'an dan Sunnah. ${ }^{26}$

Implikasi dari pandangannya itu bahwa jika suatu doktrin tidak dapat dibuktikan merupakan pancaran dari kedua sumber Islam, maka doktrin tersebut bukanlah doktrin Islam. Sedangkan tradisi kaum muslim sendiri tidak harus diterima begitu saja sebab banyak yang merupakan tradisi luar, baik pemikiran, budaya maupun institusi. Oleh karena itu untuk mendapat potret tradisi yang sesungguhnya dimensi-dimensi historis dalam Islam harus terbuka untuk dipersoalkan kembali. Pendek kata, pendekatan Rahman bersifat kritis dan dialektis, sebab ia ingin secara kritis mengkaji tradisi Islam dan bagaimana tradisi ini dibentuk. Tradisi itu sendiri tetap dipandang penting oleh Rahman mengingat tidak mungkinnya Islam terbentuk tanpa tradisi yang melingkupinya, dengan demikian suatu pemikiran Islam yang tidak berakar dari tradisi juga perlu dipersoalkan. Dalam kaitan ini Nurcholis Madjid mengomentari;

Sejalan dengan argumennya mengenai perlunya mengembangkan apa yang ia sebut "Neo-modernisme Islam" dan sesuai kritiknya kepada modernisme lama yang tersirat serta tersurat dalam argumen "Neo-modernisme" nya, Fazlur Rahman juga amat kritis

${ }^{26}$ Ahmad Amir Aziz, Pembaruan Teologi..., h. 83 terhadap pemikiran Islam yang tidak berakar dalam sejarah dan tidak relevan bagi perkembangan masyarakat. Ia memandang bahwa suatu bentuk pengembangan pemikiran Islam yang tidak berakar dalam kekayaan pemikiran klasik atau luput dari kemampuan menelusuri benang kesinambungannya dengan masa lalu adalah tidak otentik. ....Maka Fazlur Rahman adalah orang yang sangat teguh berpegang pada adagium para ulama konvensional: "al-Muhafadzah 'ala al-qadim al shalih wa al-akhdz bi al-jadid al-ashlah". ${ }^{27}$

Menegaskan apa yang telah disebut di muka, pola pembaruan neomodernisme yang dicanangkan oleh Rahman dapat dismpulkan dengan menggiring dua dimensi dan sekaligus hendak mengkompromikannya, yaitu antara tradisi dan modernitas. Menolak keduanya adalah tidak mungkin sama sekali, demikian juga menerima kedua tanpa kritisisme sama artinya dengan tidak melakukan pembaruan apapun. Oleh karena itu, mengingat target Neomodernisme adalah pemecahan masalahmasalah aktual dan rekonstruksi untuk masa depan secara utuh maka tidak dapat Neo-modernisme harus membekali dirinya dengan suatu perangkat metodologi yang tepat. Secara singkat dapat dijelaskan bahwa metodologi sistematis yang ditawarkan Rahman

${ }^{27}$ Nurcholis Madjid, Fazlur Rahman dan Rekonstruksi ..., h. 24 
bertumpu pada gerakan ganda sebagai berikut;

a. Penelaahan historis atas doktrindoktrin Islam secara ilmiah. Dalam hal

Ini konteks sosio-kultural adalah mutlak diperhatikan, karena untuk mendapatkan gagasan yang orisinal perlu dibedakan doktrin normative dan doktrin historis. upaya ini dapat diakhiri setelah berhasil merekomendasikan misi Islam secara universal dan jika perlu secara khusus dalam beberapa aspeknya.

b. Kajian atas kondisi aktual yang berkembang lengkap dengan berbagai problematikanya dan kemudian merumuskan beberapa alternatif penyelesaiannya dengan tetap berpijak pada gagasan sentral Qur'an dan Sunnah. ${ }^{28}$

Menurut Rahman sendiri metodologi seperti itu belum pernah dipraktekkan secara sungguh-sungguh dalam sejarah perkembangan Islam. Akibatnya gerakan pembaruan Islam belum mampu memberikan penyelesaian yang memuaskan atas masalah-masalah yang dihadapinya, dan dengan demikian sulit untuk memberikan perspektif ke depan. Efeknya lebih jauh dari tidak dikembangkannya metode kontekstual yang sistematis terlhat pada tulisantulisan keagamaan umat Islam pada abad pertengahan yang mana tidak dapat memberikan bimbingan yang menyeluruh untuk masa sekarang, baik itu dalam bidang teologi maupun hukum. Dalam hal ini kata Rahman, fakta yang paling jelas dalam adalah adanya proses pengadopsian gagasan-gagasan asing dalam bidang teologi dengan ketiadaan wawasan yang padu akan pandangan dunia al-Qur' an. ${ }^{29}$

Pandangan Rahman demikian memang terjadi dalam sejarah dimana aliran-aliran teologi membungkus doktrin-doktrinnya dengan gagasangagasan rasional-filosofis yang diambil dari warisan pemikiran Yunani. Meskipun sumber-sumber dari Yunani itu tidak dengan sendirinya seluruhnya bertentangan dengan Qur'an tetapi secara pasti adalah asing dan tidak jarang menunjukkan ide yang berseberangan dengan kandungan al-Qur'an. Sedangkan dalam bidang hukum menurut Rahman, efeknya terjadi dalam bentuk-bentuk ijtihad yang semata-mata ad hoc, bersifat juz'i, untuk kasus per kasus, sehingga

${ }^{29}$ Fazlur Rahman, Islam dan Modernity..., h. 3

${ }^{28}$ Ahmad Amir Aziz, Pembaruan Teologi..., h. 84 
gagal merumuskan bentuk ijtihad yang komprehensip dan berjangka panjang. ${ }^{30}$

Memang dalam kenyataannya watak hukum Islam merupakan respon atas maslah-masalah yang baru muncul dan kemudian dicarikan status hukumnya atau penyelesaiannya berdasarkan asasasas syari'ah, sehingga hukum Islam tidak pernah menghasilkan suatu teori yang menyeluruh untuk penyelesaian masalahmasalah yang muncul dalam jangka panjang. Sangat mungkin yang dilihat Rahman adalah kenyataan bahwa produkproduk hukum Islam senantiasa ketinggalan zaman mengingat laju dan denyut kehidupan sedemikian cepat bergerak dengan membawa persoalanpersoalan yang tidak sederhana, sementara dengan pemecahan masalah secara konvensional yaitu menangani kasus per kasus hanya akan membuat struktur hukum tidak sistematis dan pada gilirannya juga tidak terarah. Disinilah kiranya dapat dipahami usulan Rahman tentang perlunya membuat kerangka metodologi secara sistematis dengan bertolak pada gagasan sentral Qur'an dan Sunnah disertai dengan pendekatan baru, sehingga produk dan pemikiran teologi maupun hukum nantinya dapat makin terarah.

${ }^{30}$ Fazlur Rahman, Islam Challenges..., h. 325
Lebih rinci tentang bagaimana rekonstruksi pemikiran dalam bidang teologi dan hukum itu dinyatakan oleh Rahman sebagai berikut;

Pertama-tama, tafsiran Qur'an ini akan menyangkut Tuhan, hubungan Tuhan dengan manusia dan alam, dan peran-Nya dalam sejarah manusia dan masyarakat. dengan menjernihkan pemahaman kita tentang hakikat pentingnya Tuhan bagi keberadaan manusia di dunia ini akan dimungkinkan suatu analisis sistematis tentang ajaran-ajaran moral dan hukum Qur'an. Ajaran-ajaran moral itu pertama-tama harus disistematisasikan, berdasarkan baik prinsip-prinsip umum yang dinyatakan secara eksplisit dalam Qur'an maupun prinsip-prinsip yang tertanam dalam ucapan resmi alQur'an, dan yang terakhir ini lebih sering terjadi. Kemudian rumusan resmi Qur'an yang sebenarnya harus dipahami dalam perspektif ajaranajaran moral ini untuk memperoleh hukum yang sistematis dari alQur'an. ${ }^{31}$

Demikianlah perkembangan pemikiran Fazlur Rahman dari waktu ke waktu sampai menunjukkan sosoknya selaku pemikir Neo-modernis dan mempunyai perhatian serius terhadap aspek teologi.

\section{Kesimpulan}

Dalam konteks pembaharuan Islam, Fazlur Rahman adalah penerus kaum modernis. Namun, berbeda dengan

${ }^{31}$ Fazlur Rahman, Islam Challenges..., h. 326 
kaum modernis yang lebih banyak bertumpu pada sumber-sumber modern, ia menyarankan pijakan yang lebih kokoh terhadap akar-akar khazanah Islam klasik yang sangat kaya. Berbeda dengan kaum tradisionalis yang sering terjebak dalam romatisme berlebihan, Rahman menawarkan metodologi yang memungkinkan kekayaan yang terkandung dalam warisan Islam klasik tersebut memiliki relevansi untuk mengatasi maslah-masalah modern.

Dengan demikian Fazlur Rahman melancarkan pembaharuannya melalui gerakan neo-modernisme, yang bertujuan untuk meluruskan arah kebangkitan umat Islam sesuai dengan kehidupan modern tanpa meninggalkan akar kesejarahannya sendiri. Kemudian ia juga berpendapat perlunya penafsiran al-Qur'an yang memadai, dalam memahami al-Qur'an, yang utama harus lebih ditekankan pada tujuan "ideal moral" daripada legal spesifik. Tujuan ideal moral yang terkandung dalam ayat-ayat harus lebih diutamakan dari ketentuan legal spesifiknya. Selain itu, sasaran al-Qur'an harus juga dipahami dan ditetapkan dengan memperhatikan latar belakang sosiologis.

\section{Referensi}

1. Abu Hasan Ali Nadawi dkk, Benturan Barat Dengan Islam, (Bandung : Mizan, 1993)

2. Abd. A'la, Dari Neomodernisme ke Islam Liberal: Jejak Fazlur Rahman Dalam Wacana Islam Indonesia, (Jakarta: Yayasan Wakaf Paramadina, 2003),

3. Ahmad Amir Aziz, Pembaruan Teologi Perspektif Modernisme Muhammad Abduh dan Neomodernisme Fazlur Rahman, (Yogyakarta: Teras, 2009)

4. Ahmaad Syafii Maarif, Peta Bumi Intelektual Islam, (Bandung: Mizan, 1994),

5. Djohan Effendi, Pengantar ke Pemikiran Iqbal, (Bandung: Mizan, 1985

6. Fazlur Rahman, Metode Alternatif Neomodernisme Islam, (Bandung: Mizan, 1993)

7. Islam, terj. Senoaji Saleh, (Jakarta: PT Bumi Aksara, 1987

8. Islam dan Modernity, (Chicago, The University of Chicago Press, 1982)

9. An Autobiographical Note, (New York: Ballatine Bookers, 1985),

10. Islam Challenges and Opportunities, (Eidenburgh: University Press, 1979)

11. Harun Nasution, Pembaharuan Dalam Islam, Sejarah Pemikiran dan Gerakan, (Jakarta: Bulan Bintang, 1975)

12. Pembaharuan Dalam Islam: Sejarah Pemikiran dan Gerakan, (Jakarta: Bulan Bintang, 1992)

13. Muhammad Azhar, Fiqih Kontemporer Dalam Pandangan Neomodernisme Islam, (Yogyakarta: Pustaka Pelajar, 1996)

14. Nurcholis Madjid, Fazlur Rahman dan Rekonstruksi Etika Al-Qur'an, (Jakarta: Islamika, 1993)

15. Syahrin Harahap, Islam dan Modernitas (Dari Teori Modernisasi Hingga Penegakan Kesalehan Modern), (Jakarta: Prenadamedia Group, 2015)

16. Syukri Saleh, Metodologi Tafsir Kontemporer Dalam Pandangan Fazlur 
Rahman, (Jambi: Sulthan Thaha Press, 2007)

17. Taufik Adnan Amal dan Ihsan Ali Fauzi, Fazlur Rahman: Sang Sarjana Sang Pemikir, (Jakarta: Lembaga Studi Agama dan Filsafat, 1988)

18. Taufik Adnan Amal, Metode dan Alternatif Neo-Modernisme Islam Fazlur Rahman, (Bandung: Mizan, 1993). 